右室流出路再建よりみたファロー四徵症根治術の検討

札幌医科大学胸部外科（主任：小松作藏教授）

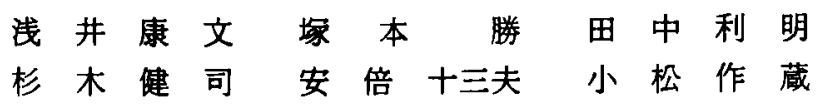

1980年 4 月より1983年12月末までにフフロ一四徴症44例に根治手術を行い, 早期死亡 は3 例 (6.8\%)であった。このらち血行動態を検索し得た40例について，右室流出路再 建法に用いた材質と手術法について検討した。

40例の男女比は22：18, 手術時年龄は 4 56歳, 平均11歳であった。手術法は全例, Young 氏液使用下に驰爱性心停止とし，心筋保讙を行い，心筇温を $15^{\circ} \mathrm{C}$ 前後に維持した. 右室流出路異常筋束切除は全例に行い，ついで心室中隔欠損孔ハッチ閉鎖，右室流出路 再建を行った，右室流出路再建は，肺動脈弁形成 3 例 ( I 群，平均24藏), EPTFE を用 いた右空バッチ再建 4 例(II群, 平均31歳)，1 并付きクルタールアルデヒド処理ブタ心 膜ヘッチ（Rygg）による右室および肺動脈再建 5 例 (III群，平均27歳)，1 弁付き自己心 膜およびEPTFE 複合バッチによる右室・肺動脈再建28例（IV群，平均 7 藏）である.

I 群は他群に比较して, 主肺動脈対上行大動脈直经比が $0.67 \pm 0.31$ と発青が良好で あった。

右室・肺動脈圧較差は，他群に比しIII群で压較差の残存がみられた。これはIII群が短 絡手術後の成人例で，右室流出路狭窄が進行しており，最小限の心筋切除とバッチ抬大 を行ったか，右室内狭窄除去が十分でなかったためであるＩV群は肺動脈拡張期王 $(13.8 \pm 0.8 \mathrm{mmHg})$ が比較的維持され，肺動脈并閉鎖不全の程度が俥圣い傾向を示してい た.

1 弁付き自己心膜と EPTFE 複合ハ・ッ使用による右室流出路桩大術は，長期予後に 問題があるとされているが，安定した成績を示し，ほぼ完成された右室流出路再建法と 考える。

事引用語：フォロー四改症，一弁付き自己心膜, 肺動脈弁閉鎖不全

はじめに

複雑心奇形に対する手術成績は，術前の正確な血行 動態の把握, 心筇保護法の導入, 術中, 術後の患者管 理の向上により，安定した手術成績を収めるよ5に なってきた。教室において1980年 4 月より1983年12月 末までにフっロ一四徽症44例に根治手術を行い，早期 死亡は 3 例（死亡率：6.8\%）であった。

このらち血行動態を検索し得た40例について, 右室 流出路再建法に用いた材質と手術法について検討した ので報告する。

\section{1. 対象と方法}

40例の男女比は22：18で, 手術時年龄は 4 56歳(平 均11歳) で, $4 \sim 10$ 歳25例, $11 \sim 20$ 歳 7 例, 20 歳以上
8 例である.

根治手術前に姑息手術を受けていた症例は16例 (40\%)で，Blalock-Taussig 吻合 8 例，Waterston 吻 合 3 例，右室流出路異常筋束切除之肺動脈弁形成術 1 例， 2 回以上の姑息手術は 4 例である。

手術法は全例, Young 氏夜使用下に弛䌅性心停止々 L, SMC (Sapporo Medical College) solution 及び ice slush にて心筋保護を行い心筋温を $15^{\circ} \mathrm{C}$ 前後に維 持した. 右室流出路異常筋束切除は全例に行いついで 心室中隔欠損孔バッチ閉鎖, 右室流出路再建を行った。 右室流出路再建法別に 4 群にわけ, 各群について, 手術成精および㭪前後の肺動脈升機能を含む血行動態 を検討した（表 1 )。 


\section{表 1 各䅲右室流出路应大衍}

\begin{tabular}{|c|c|c|c|}
\hline \multicolumn{2}{|c|}{ Method of RVOT reconstruction } & No. of Patients & \multirow{2}{*}{$\begin{array}{l}\text { Age at } 0 p . \\
11-29(24)\end{array}$} \\
\hline Group 1 & 1) Infundibulectomy & 3 Cases & \\
\hline Group II & $\begin{array}{l}\text { 1) Infundibulectomy } \\
\text { 2) RV EPTFE patch }\end{array}$ & $4(1)$ & $8-56(31)$ \\
\hline Group III & $\begin{array}{l}\text { 1) Infundibulectomy } \\
\text { 2) Rygg pericardial patch }\end{array}$ & 5 & $18-38(27)$ \\
\hline Group IV & $\begin{array}{l}\text { 1) Infundibulectomy } \\
\text { 2) Autologous pericardial valved } \\
\text { patch ₹ EPTFE patch }\end{array}$ & $28(2)$ & $4-16(7)$ \\
\hline & Total & 40 (3) Cases & \\
\hline
\end{tabular}

RVOT (Rt ventricular outflow tract) 1980.4. - 1983. 12.

I 群は肺動脈弁形成施行例で 3 例 (平均年龄24歳)， II 群は EPTFE (expanded polytetrafluoro ethylene) を用いた右室ハッッ再建で 4 例(平均年龄31歳)，III群 は1并付きクルタールフルデヒド処理ブタ心膜ハッチ (Rygg)による右室拉よび肺動脈再建例で 5 例(平均年 龄27歳)，IV群は 1 弁付き自己心膜および EPTFE 複 合ハッチによる右室・肺動脈再建28例（平均年龄 7 歳） である。

\section{2. 結 果}

a. 手術成績：I群およびIII群では手術死亡例はな く，II群で 1 例，IV群で 2 例を失った，II群の死亡例 はBlalock 手術15年後の56歳女性で術前より左室容 量の狭小を認め, 術後出血による再開胸後に低心拍出 量应候群（LOS）で失った. IV群の死亡 2 例のうち 1 例は conus defect 型心室中隔欠損症で， 2 例とも術直 後より尿量减少，末梢循環不全を示し LOS で失った。

b. 術前主肺動脈対上行大動脈直经比(PA/AO

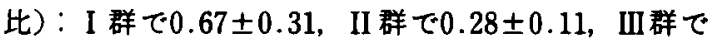
$0.34 \pm 0.08$, IV 群は0.37士0.09 (mean士SD) であっ た.I群は他群に比して肺動脈の発育はよく，II， III, IV群間には有意差はなかった。

C. 術後心カテーテル検查所見：各群において, 術後 6 週前後で施行した心葴カテーテル検査所見（表 2） は,

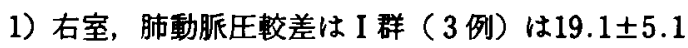
$\mathrm{mmHg}$, II 群 ( 3 例) は27.5 $\pm 8.7 \mathrm{mmHg}$, III 群 ( 5 例)

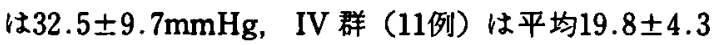
$\mathrm{mmHg}$ と, I , IV群で圧較差の低下を認め, III群で圧較 差の残存がみられた。

2）右室対左室收樎期圧比は，I群で $0.32 \pm 0.04$, II

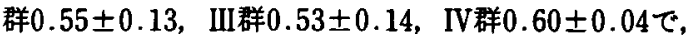
I 群で有意の低下を示し，II，III, IV群間には有意差は みられなかった。
表 2 衍後，カテーテル所見およひ心谈能.

\begin{tabular}{|l|cccc|}
\hline \multicolumn{1}{|c|}{ Group } & $I(n-3)$ & II $(n-3)$ & III (n-5) & IV (n-11) \\
\hline preoperative PAIAO & $0.67 \pm 0.31$ & $0.28 \pm 0.11$ & $0.34 \pm 0.08$ & $0.37 \pm 0.09$ \\
\hline Postoperative cathe. & & & & \\
RV - PA & $19.1 \pm 5.1$ & $27.5 \pm 8.7$ & $32.5 \pm 9.7$ & $19.8 \pm 4.3$ \\
RV I LV & $0.32 \pm 0.04$ & $0.55 \pm 0.13$ & $0.53 \pm 0.14$ & $0.60 \pm 0.04$ \\
Cardiac Index & $5.2 \pm 1.1$ & $3.2 \pm 0.5$ & $2.9 \pm 0.8$ & $5.3 \pm 1.3$ \\
R V S W I & $6.8 \pm 1.3$ & $5.2 \pm 1.2$ & $4.7 \pm 2.7$ & $8.4 \pm 3.1$ \\
LV S W I & $62.8 \pm 13.3$ & $34.2 \pm 9.7$ & $33.9 \pm 13.1$ & $46.26 \pm 14.9$ \\
\hline P A D P & $10.2 \pm 0.7$ & $6.2 \pm 1.5$ & $8.5 \pm 1.8$ & $13.8 \pm 0.8$ \\
PADP - RVEDP & $5.2 \pm 0.8$ & $4.2 \pm 1.3$ & $4.6 \pm 2.0$ & $10.1 \pm 1.6$ \\
PA pulse pressure & $0.67 \pm 0.15$ & $0.74 \pm 0.07$ & $0.76 \pm 0.03$ & $0.68 \pm 0.11$ \\
\hline PA systolic pressure & & & &
\end{tabular}

3）心係数, 右室仕事量, 左室仕事量は表 2 に示すご とく，I，IV群で良好であった。

d. 術後肺動脈弁閉鎖不全 (PR) の評価：肺動脈拡 張期圧 (PADP)， PADP一右室終末払張期圧 (RVEDP) および肺動脈脈圧 (PA pulse pressure)/肺 動脈収縮期圧 (PA systolic pressure) の3つより評価 を行った。

PADPは表 2 のごとく，I群 $(10.2 \pm 0.7 \mathrm{mmHg})$, IV群(13.8 $\pm 0.8 \mathrm{mmHg})$ は, II，III群に比較して PADP は比較的よく維持されていた。

PADP-RVEDP は，IV群で10.1士1.6mmHg と他 群に比して高值を示したが，他群との間に統計学的に 有意差はみられなかった。

PA Pulse pressure /PA systolic pressure は, 4 群 間に有意差はみられなかった。

\section{3. 考 察}

数室でのフナロー四徽症に対する手術方針は, 乳児 期に無酸素発作を起こし，プロブラロノールを必要と する症例は，早期に Blalock Taussig 手術を行 5. 短 絡は原則として肺動脈低形成側に行らが, 鎖情下動脈 が細く短い場合にはEPTFEクラフトによる modified Blalock 手術（鎖骨下動脈と肺動脈間のハイ パスクラフト) を行5.3歳以上となると，ほとんと の症例が根治手術の適応となる1!.

数室での根治手術の成績す次第に向上し，1980年 4 月以降の根治手術44例中, 早期死亡 3 例(死亡戠 $6.8 \%$ ) のみで，最近の32例では死亡例はなく連続して良好な 経過をとっており，カテュラミン非使用例む増加して いる.この手術成績向上の重要な因子として, 右室流 出路拡大法が関係している. 肺動脈弁交連切開のみで は不充分で，弁輪を越えて右室流出路形成を必要とす る症例では，PR 予防のため,成人例にはグルタールア ルデヒド処理した 1 弁付きブタ心膜 (Rygg)を，また 小児例では自己心膜を採取し，1 弁付きハッチを作成 
し，右室部はEPTFE 布によるパッチとなるように複 合ハッチを作成し, 右室流出路再建を積極的に行って いる.

成人例に使用した 1 弁付き Rygg ブタ心膜は曰井 らの術後心音図での肺動脈第 II 音および超音波診断 で弁機能がよく保たれていたとの報告すあるが，石灰 化を含さ将来の変化に注意して観察していく必要があ る.

教室では小児において肺動脈弁陯を越えて右室流出 路形成を行う場合, 1 弁付き Rygg ブタ心膜は, (1)小览 用の適当な大きさのbのがないこと，(2)高価なこと， (3)特に小児ではグルタールアルデヒド処理した生体弁 の石灭化の報告があること, 初回手術が多く自己心膜 を使用できるなどの理由で使用していない。

教室での 1 弁付き自己心膜+EPTFE椱合ハッッチ は, 図 1 のごとく, 台形の心膜に, 巾約 $20 \mathrm{~mm}$, 深さ約 15mm の弁を作成し，これに5-0ポリプロビレン系 で, EPTFE人工血管を切り開きパッチとして䋖着し ている. 挥着時の注意点として EPTFEハッチでは針 穴による出血がみられることから，針の刺入のし直し をしないこと，また，血栓予防のため糸の結禁はかな らず外側で行うょらにしている.図 2 はできあがりで， 心膜部は必要に応じてトリミングし，EPTFEハッチ 部分は右室流出路切開創にあわせて使用している、現 在のところ，術後この方法で弁に石灰化をみた症例は ない. 弁付さハッチの装着方法は, 大須賀 ${ }^{3} の$ 報告のご とく，固有肺動脈弁を可及的に温存するように，弁輪 部切開線は交連切開線と一致させ，心膜弁が狭窄を解 除された固有肺動脈弁と良く適合するよらに徏着する

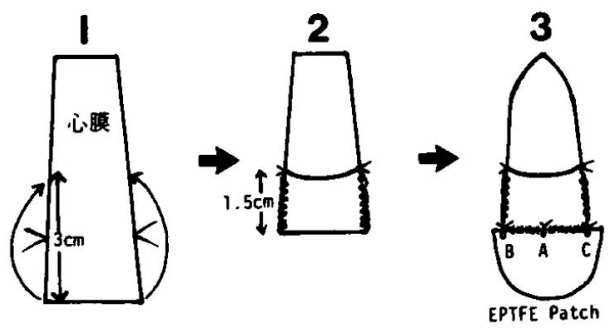

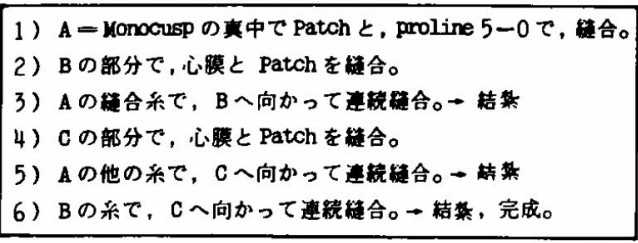

图 11 井付き自己心搭おょび EPTFE 被合パッチ 作成法。

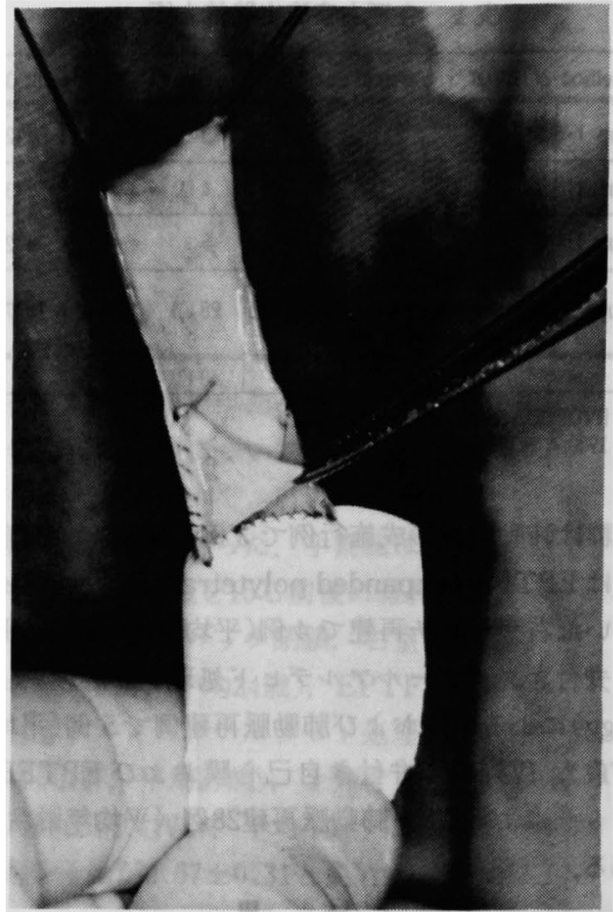

図2完成図

ことが大切である。しかし，本法は遠隔期まで弁機能 が保持されることは期待できないとの報告》すあり， 自己肺動脈弁の温存とその発育を促す工夫も大切であ る.

右室流出路形成において生じたPR は，容量負荷に て遺残短絡と同じ影響を右室に与え，右室㧪張期王を 上昇させる。この PR 予防のため, 前述の方法以外に, 最近雑種犬を使用した新しい方法の実験成績が報告さ れている，1つは肺動脈前壁を内側に折り曲げて肺動 脈弁輪上に 1 并を形成し，その上を自己心膜で覆ら方 法)で他はダルールフルデヒド処理した牛心膜を用 い, コンビューター分析に上り，正常構造にデザイン され型どられたバルサルバ洞をるつ composite monocusp patch 法6)である.

手術において肺動脈弁輪を越える場合の右室流出路 払大基準は，加畑》にによると正常人の体表面積当たり の肺動脈弁輪内经の平均値が最す妥当であり，再建す る弁输の大きさはこの平均值と正常人の上限値の中間 に作成すれば充分な術後の右室・大動脈圧比の下降が 得られるとしている. 教室です Rawlatt の正常人体表 面積当たりの肺動脈弁輪内径の平均値を参考に䢁大 し, Hegar 払張器にてその大きさを確認している. 
右室流出路側ハッチは, 強力な収縮力を持つ右室洞 部へバッチがかかることを避けるよらにするため，右 室切開は心要最小限にとどめる。このパッチに心膜を 使用した場合，遺残短絡，PR，三尖弁閉鎖不全のよう な容量負荷や，遺残狭窄のような王負荷が加わると膨 隆し，瘤を形成する。また Ruzylloら ら1は，流出路パッ チより遠位部での㹟窄が, 心膜ハッチの動脈瘤様执張
の原因となりらると述ぺており教室でも同様な症例を 経験している（図３）。教室の右室部ハッッは厚手の EPTFEのため, 右室部が収樎期に膨隆したり, 奇異運 動を呈することはなく，血液の漏れもない。

これら右室流出路形成後の PR の判定には, 確立さ れた方法はない。

Albertal ${ }^{99}$ はPR の指標として, PA pulse Pressure/

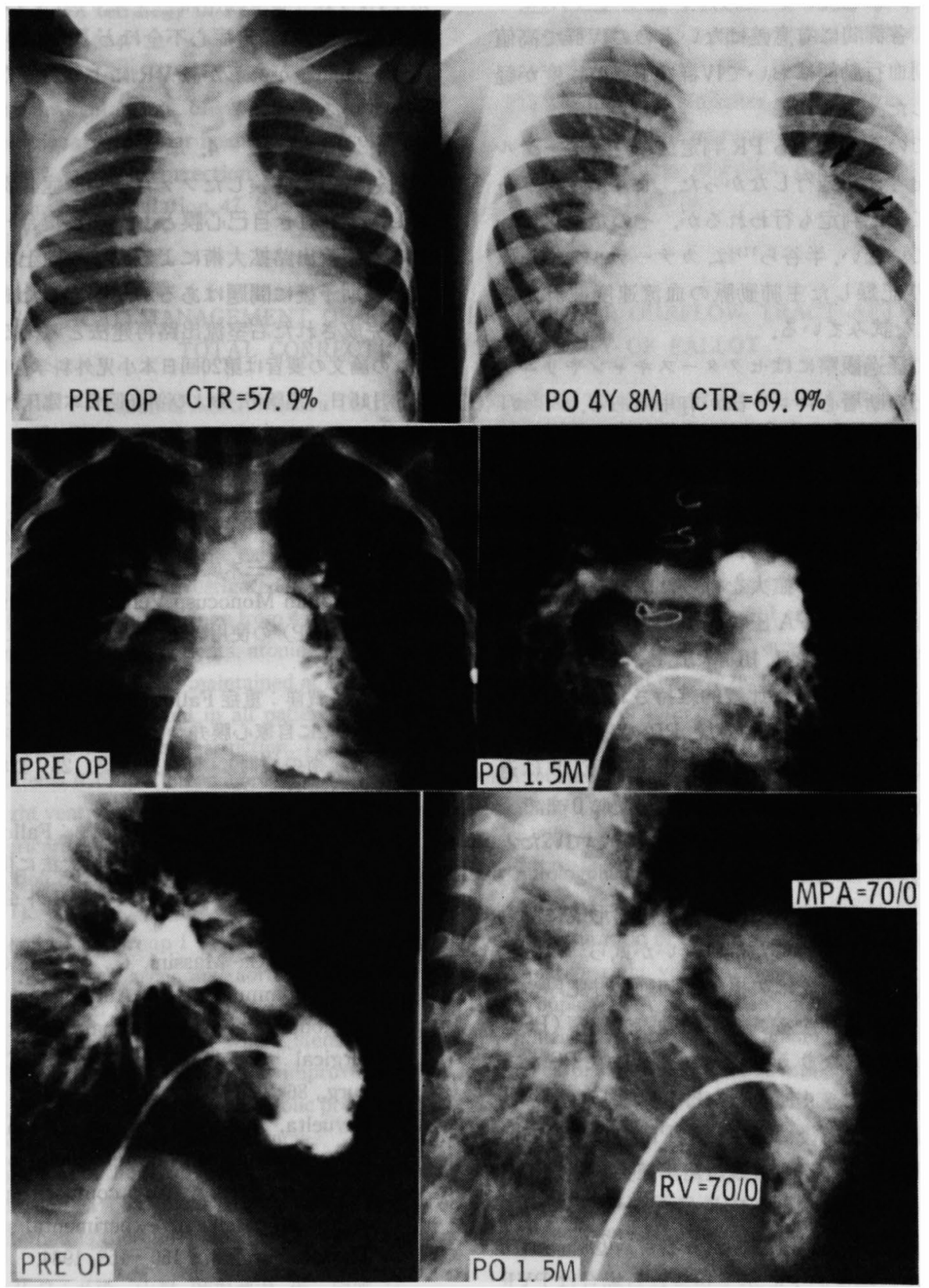

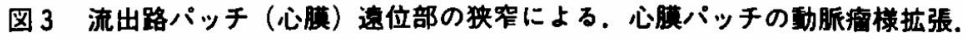


PA systolic pressure の比を用い遠隔成績を検討し, この比の正常値を $0.33 \sim 0.55$ と報告している.教室の 4 群間には有意の差はないが，I群とIV群は正常値に 近い値を示した。

Jones $ら^{10}$ は, PAEDP とRVEDP が近似し，かつ軽 度の収縮期圷較差があれば PR とし，この場合の収縮 期圧較差は，遺牫狭窄のためでなく，血流由来である としている.教室例ではPADP およびPADPー RVEDP で，各群間に有意差はないるののIV群で高値 を示し，早期血行動態においてIV群は PR の程度が軽 い㑯向を示した。

主肺動脈での造影による PR 判定法は，カテーテル による影響を考え，施行しなかった．またドップラー エコー法にて PR 判定む行かれるが，その定量化はい まだ確立していない. 半谷ら"1は,カテーテル先端電磁 流速計により記録した主肺動脈の血流速度波計から PRの定量化を試みている。

肺動脈弁の経過観察にはセクタースキャンやリニフ スキャンなどの断層心ェコー法が有用である。

教室の右室流出路形成に拈いて, I 群は PA/AO 比 が他群に比し良好で、流出路ハッッを必要としなかっ たため，術後心機能は良好であった。ＩII群では短絡手 術後の成人例で，右室流出路㹟窄が進行しており，最 小限の心筋切除とバッチ拡大を行ったが右室内狭窄除 去が十分でなく，RV-PA 欧較差が大きい傾向を示し たと思われる、IV群は，II，III群に比し，右室・肺動脈 代較差が少なく，PADP が比較的維持され，PADP一 RVEDP か $10.1 \pm 1.6 \mathrm{mmHg}$ あり，PRの程度が軽い 傾向を示していた，大須賀》か PADP-RVEDPは退 院時 $6.2 \pm 3.9 \mathrm{mmHg}$, 全体の $32 \% て ゙$ 遠隔期に0まで下 降したが，68\%は有意の払張期压較差を有していたと 報告している。

以上のごとく教室の症例では右室流出路形成に肺動 脈并置換術（PVR）を行った例はないが武ら ${ }^{13}$ は，(1) 肺動脈并の低形成すしくは久損，(2)肺動脈弁肥厚や变 形が著しく，弁を温存することが肺動脈弁㹨窄 (PS) またはPR の原因となりらる場合，(3)高度なPSがあ り，肺動脈弁輪を大きく拻大しなければならない例， (4)肺動脈升輪の扗大術後に発生したPRのための右心 不全，(5)肺動脈末梢狭窄中遭残短絡，三尖弁閉鎖不全 などの右心不全を增覀させる因子があり，軽度のPR で右心不全となることが予想される場合，(6)肺高血圧 症があり，術後に高度の PRが予想される場合はPVR の適応となるとしている。松川ら ${ }^{161}$ は左肺動脈低形成
を伴ら9歳および衍後肺高血圧症の予想される23歳 ファロ一四改症に対し，肺動脈弁位（in situ）におけ る Ionescu-Shiley 生体并置換による根治術を報告し ているか，遠隔期での石灰化による弁機能不全の報告 ああり，その適応には原疾患，年龄などを考虑して慎 重に決定しなければならない. Miller ら 四徴症根治術晚期に右心系の再建を要した28例の再手 術中, PVR+右室流出路ハッチ8 例, PVR+三尖弁置 換 2 例を経験し, 重症心不全ほど PRの影䈉が強く, 遠 隔予後に問題があるが, PVRにより良好な経過を得た としている.

\section{4.まとめ}

最近教室で経験したファロー四徽症40例について検 討し，.1弁付き自己心膜と EPTFE 複合バッチ使用に よる右室流出路拡大術による成綨の向上を述べた，本 法は長期予後に問題はあるが，安定した成樍を示し， ほぼ完成された右室流出路再建法と考える.

この論文の要旨は第20回日本小児外科学会総会（昭和58 年 5 月15日, 福岡市) お上び第46回日本臨床外科医学会(昭 和59年11月17日，東京）において発表した。

\section{文献}

1）浅井康文，安倍十三夫，小松作蔵：先天泩心疾患の 外科的治療，小児内科，15:1741-1746，1983.

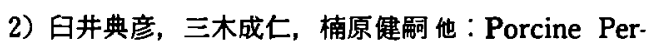
icardium Monocusp Ventricular Outflow Patch (MVOP) の使用経鏂, 胸部外科, $36: 103-109$, 1983.

3）大原賀洋：重症 Fallot 四徽症に対する外科治庵 (とくに自家心膜升つきバッチによる右室流出路 再建術の娭討), 日胸外会誌, 28：1288-1303, 1980.

4）加畑 治, 佐藤成和, 横山 温他：Fallot 四徽症根 治手術における右心流出路抬大法に阅する研究 (第 II 編, 実的研究), 日胸外会誌, 29： $1263-1271,1981$.

5) Iacobone, G., Massini, C., Noera, G., et al.: Brief communications-Autologous monocusp pulmonary valve : Preliminary results of a new surgical technique. J. Thorac. Cardiovasc. Surg., 86 : 930-934, 1983.

6) Revuelta, J., Val, F. and Duran, C.M.G.: Reconstruction of right ventricular outflow and pulmonary artery with a composite pericardial monocusp patch : An experimental study. Ann. Thorac. Surg., $37:$ 150-153, 1984.

7) 加畑 治, 佐藤成和, 横山 温他：Fallot 四徵症根 治手術に和ける右心流出路拡大法に関する研究 
(第 1 編, 臨床的研究), 日胸外会誌, 29 ： 1255-1262, 1981.

8) Ruzyllo, W., Nihill, M.R., Mullins, C.E., et al.: Hemodynamic evaluation of 221 patients after intracardiac repair of Tetralogy of Fallot. Am. J. Cardiol., 34 : 565-576, 1974.

9) Albertal, G., Swan, H.J.G. and Kirklin, J.W.: Hemodynamic studies two weeks to six years after repair of tetralogy of Fallot. Circulation, 29 : 583-592, 1964.

10) Jones, E.L., Coniti, C.R., Neill, C.A., et al. : Long-term evaluation of tetralogy patients with pulmonary valvular insufficiency resulting from outflow-patch correction across the pulmonic annulus. Circulation, 47, 48(Suppl. III) : 11 $-18,1973$.
11）半谷静婎, 石原 昭：カテ先電磁流速形を用いた 肺動脈閉鎖不全の定量的評価法。第19回日本小児 循環器学会抄録集, p. 328-329, 1983.

12）中村洋樹, 大石喜六, 小須賀健一他：ファロー四徽 症における右室流出路再建の検討．第19回日本小 児循環器学会抄録, p. $424-425,1983$.

13）武涪，上次悠，原田三紀夫他：肺動脈弁置 換, 胸部外科, $36: 855-862,1983$

14）松川哲之助, 横次忠夫, 橋本良一他：Fallot 四改症 根治術における in situ肺動脈弁置撸の意義, 胸部 外科, $33 ： 581-585 ， 1980$.

15) Miller, D.C., Rossiter, S.J., Stinson, E.B., et al.: Late right heart reconstruction following repair of Tetralogy of Fallot. Ann. Thorac. Surg., 28 : 239-251, 1979.

\title{
SURGICAL MANAGEMENT OF RIGHT VENTRICULAR OURFLOW TRACT AFTER TOTAL CORRECTION OF TETRALOGY OF FALLOT
}

\author{
Yasufimi ASAI, Masaru TSUKAMOTO, Toshiaki TANAKA, Kenji SUGIKI, \\ Tomio ABE and Sakuzo KOMATSU \\ Department of Thoracic and Cardiovascular Surgery, Sapporo Medical College
}

Radical surgery was performed in 44 patients with tetralogy of Fallot between April 1980 and December 1983. Three patients $(6.8 \%)$ died in the early stage. Materials and techniques used for the reconstruction of the right ventricular outflow tract were investigated in 40 patients in whom hemodynamics could be determined.

The 40 patients ranged in age from 4 to 56 at the time of surgery, with a mean age of 11 and a male/female ratio of 22:18. For surgery, in all patients, atonic cardiac arrest was induced during the use of Young's solution, and cardiac muscles were protected and maintained at about $15^{\circ} \mathrm{C}$. Excision of abnormal muscle bundles at the right ventricular outflow tract was performed in all patients, followed by patch closure of interventricular septal defect and right ventricular outflow tract reconstruction. The techniques of this reconstruction were formation of the pulmonary valve in three patients (Group I, mean age 24), right ventricular patch reconstruction using EPTFE in four (Group II, mean age 31), right ventricular and pulmonary arterial reconstruction using a glutaraldehyde-treated single-valve-containing porcine pericardial patch (Rygg) in five (Group III, mean age 27), and right ventricular and pulmonary arterial reconstruction by a combined patch of single-valve-containing autologous pericardium and EPTFE in 28 (Group IV. mean age 7).

Development in Group I was better than in other groups, with the ratio of the diameter of the main pulmonary artery to that of the ascending aorta being $0.67 \pm 0.31$. A relative right ventricular-pulmonary artery pressure difference remained in Group III as compared with the other groups. This was because patients in Group III were adults after shunt surgery, in whom stenosis of the right ventricular outflow tract advanced and the right intraventricular narrowing was not fully improved even by minimal cardiac muscle resection and patch enlargement. In Group IV, the pulmonary arterial diastolic pressure $(13.8 \pm 0.8 \mathrm{mmHg})$ was comparatively well maintained, showing a tendency of mild pulmonary insufficiency.

Enlargement of the right ventricular outflow tract by using a combined patch of single-valve-containing autologous pericardium and EPTFE is said to be unsatisfactory in long-term prognosis. However, our cases showed stable results, and this method is therefore considered to be an almost perfect procedure for right ventricular outflow tract reconstruction. 